Збірник наукових праць. Серія: Галузеве машинобудування, будівництво

Academic journal. Series: Industrial Machine Building, Civil Engineering

http://journals.pntu.edu.ua/znp

https://doi.org/10.26906/znp.2018.51.1302

UDC 624.21:625.745.2

\title{
Influence of residential complex construction on the condition of the sewage collector and the underground water supply system in Kyiv on A. Barbyusa st.
}

\author{
Shuminskiy Valerii ${ }^{1 *}$, Stepanchuk Serhiy ${ }^{2}$, Dombrovskyi Yaroslav ${ }^{3}$, \\ Kostetzkay Svitlana ${ }^{4}$, Kostochka Yegor ${ }^{5}$ \\ ${ }^{1}$ The State Research Institute of Building Constructions (Kiev) https://orcid.org/0000-0002-8751-1983 \\ ${ }^{2}$ The State Research Institute of Building Constructions (Kiev) https://orcid.org/0000-0002-5591-1827 \\ ${ }^{3}$ The State Research Institute of Building Constructions (Kiev) https://orcid.org/0000-0003-0687-1256 \\ ${ }^{4}$ The State Research Institute of Building Constructions (Kiev) https://orcid.org/0000-0002-1799-6006 \\ ${ }^{5}$ The State Research Institute of Building Constructions (Kiev) https://orcid.org/0000-0002-8098-3531 \\ *Corresponding author: shumikvd@gmail.com
}

The article presents the design features of a residential complex located in the Barbyus street in Kyiv. The main city sewer and water supply is the basis of the residential designed complex. It is necessary to consider the possible impact of new residential complex construction on the sewer and water supply. To assess this effect, the stress-strain state in the soil around the collector and water supply system has been analyzed. Conclusions are drawn concerning the technical condition of the sewer and water supply system after residential complex construction and its further operation.

Keywords: collector, water supply, stress-strain state, building, designing, construction

\section{Вплив будівництва житлового комплексу по вул. А. Барбюса в Києві на стан каналізаційного колектора та підземного водогону}

\author{
Шумінський В.Д. * , Степанчук С.В. ${ }^{2}$, Домбровський Я.І. ${ }^{3}$, Костецька С.М. ${ }^{4}$, Косточка С.Г. \\ 1, 2, 3, 4, 5 ДП «Державний науково-дослідний інститут будівельних конструкцій», м. Київ \\ *Адреса для листування: shumikvd@gmail.com
}

\begin{abstract}
Наведено особливості проектування житлового комплексу, розташованого по вул. А. Барбюса в м. Києві. Зазначено, що особливістю проектування житлового комплексу є те, що в грунтовій основі комплексу, котрий проектується, на глибині 39,0...42,0 м (від поверхні землі) проходить головний міський каналізаційний колектор, а на глибині 55,5 м напірний водогін Деснянського водопроводу. При проектуванні житлового комплексу було передбачено конструктивні заходи у вигляді відсічних стінок зі зменшення впливу нового будівництва на каналізаційний колектор та напірний водогін. Необхідно було враховувати можливий вплив нового будівництва житлового комплексу на каналізаційний колектор і водогін з урахуванням ужитих конструктивних заходів та за необхідності надати рекомендації щодо зменшення негативного впливу. Для оцінювання цього впливу було розроблено розрахункову модель системи «будівля - фундамент - грунтова основа», в якій оцінювалася зміна напружено-деформованого стану ( далі - НДС) у грунті навколо колектора і водогону, а також у несучих конструкціях колектора й водогону, та відповідні деформації й зусилля, що створюють НДС і виникають у конструктивних елементах колектора, водогону та в грунті. Зроблено висновки щодо зміни технічного стану каналізаційного колектора та водогону після будівництва житлового комплексу та його подальшої експлуатації і наведено рекомендації щодо виключення можливого виникнення аварійної ситуації на колекторі та/або водогоні й необхідності оцінювання впливу будівництва житлового комплексу на існуючу оточуючу забудову.
\end{abstract}

Ключові слова: колектор, водогін, напружено-деформований стан, будівля, проектування, будівництво 
Introduction. Residential complex which is being designed is located in the Barbyus st. in Pecherskyi District of Kyiv and its size is $138 \times 108 \mathrm{~m}$. For the moment the most of the city territories with flat relief, convenient geotechnical conditions, and absence of geohazards and other unfavorable conditions are built up. Therefore, the engineering-geological risk of developing such territories increases as well as the risk of emergencies. It caused a decreasing in free areas with favorable conditions for construction in Kyiv and necessitated new construction objects designing and building in the areas with complex geotechnical conditions, the landslide and landslide-hazard areas, zones affected by geohazards and other hazardous engineering risks.

Beneath the construction site of a residential complex, which is built, at $98.1 \mathrm{~m}$ level (at depths of $39 \ldots$ $42 \mathrm{~m}$ ) the main city sewer collector is located along with the pressure water pipe (at depths of $55.5 \mathrm{~m}$ ) that belongs to Desnianskyi water supply system.

Analysis of recent sources and publications. The issue of buildings and structures construction in the convenient and complex geotechnical conditions as well as in the zones of geohazards influence, the bases reinforcement methods, structural solutions of protective structures, and other hazardous engineering risks are addressed by a set of regulations and standards, that is: DBN V.2.1-10 and its Amendments № 1 and № 2, DBN V.1.1-45, DSTU-N B V.1.1-39, DSTU-N B V.1.1-40, DSTU-N B V.1.1-44 [1-7].

Identification of unsolved issues in the problem under consideration. The existing set of standards and regulations on designing in convenient and complex geotechnical conditions, as well as in the zones of geohazards influence, and other hazardous engineering risks does not completely provide the opportunity of buildings and structures design at the modern level.

Introduction of new DBN V.2.1-10:201X «Bases and foundations of buildings and structures. Basic provisions» and standards in its development enable to update the set of regulations on buildings and structures design on landslide and landslide hazardous areas, territories with convenient and complex geotechnical conditions, in zones of geohazards influence including seismic impacts.

Problem statement. Improvement of existing state construction codes $[1-3]$ in the field of buildings and structures bases and foundations design, considering the modern principles of their design through development of DBN V.2.1-10:201X enables to takethe reasonable decisions on calculations and to justify technical decisions on areas with dangerous engineering risks. These norms are an integral part of a set of standards and regulations that establish mandatory requirements for buildings and structures design on different constructions sites with different geotechnical conditions and that are intended for use at all stages of the life cycle of construction objects.

Main material and results. In the draft of DBN V.2.1-10:201X the basic provisions are shown as well as requirements for all types of buildings and structures bases and foundations design, construction and reconstruction and classes of consequences (responsibilities), the basic requirements for bases engineering treatment design are contained as well as the composition of engineering surveys, environmental requirements for the buildings and structures bases and foundations design. The article presents the use of the standards and regulations set when designing a specific construction object, complicated by hazardous engineering risks, connected with the location of an underground sewer collector in the development spot (at depths of $39 \ldots 42$ from the surface) and pressure water pipe (at depth of $55 \mathrm{~m}$ from the surface).

The sewer collector is located under the buildings $\mathrm{A}$ and $\mathrm{B}$, and the water pipe runs directly under the building A (Figure 1).

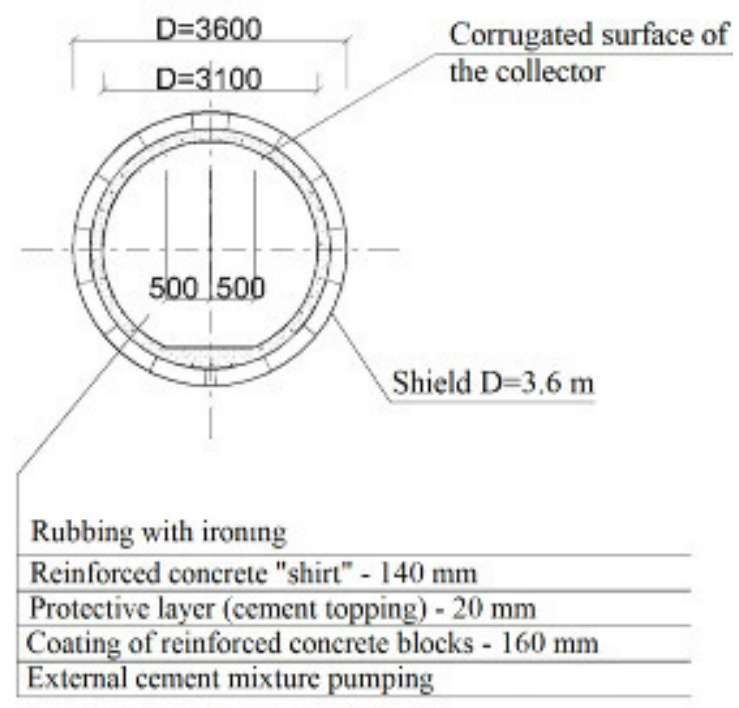

\section{Figure 1 - Cross section along the sewer collector}

The designed residential complex includes a stylobate part and three high-rise buildings [8] (Fig.1):

1) building «A» $-99,05 \mathrm{~m}$ tall, has 22 residential floors, 2 technical and 3 underground floors;

2) building $\langle\mathrm{B}\rangle-123,65 \mathrm{~m}$ tall, with 29 residential floors, 2 technical and 3 underground floors;

3) Building «C» $»-123,65 \mathrm{~m}$ tall, has 29 residential floors, 2 technical and 3 underground floors.

All the buildings belong to the structures of significant consequences $\mathrm{CC} 3$.

The foundations of buildings are plate-grid piles. The piles diameter is $\varnothing 820 \mathrm{~mm}$, the length is $25,0 \mathrm{~m}$ (the bottom level is $103,35 \mathrm{~m}$ ), carrying capacity $303,5 \mathrm{t}$, the thickness of a plate grid is $1500 \mathrm{~mm}$. In the zone of the sewer collector location, the thickness of the plate grid is $2000 \mathrm{~mm}$. The grid is supported by piles with the length of $35,0 \mathrm{~m}$ (the bottom level is $92,85 \mathrm{~m}$ ) and carrying capacity of $450 \mathrm{t}$. Piles are located from both sides of the collector at a distance of 5 $\mathrm{m}$. There are no piles directly above the collector [1]. In the stylobate part of the project, there are three underground floors which height is $3,15 \ldots 4,20 \mathrm{~m}$. 
The design provides for constructive measures to reduce the negative impact of the residential complex construction on a collector, that is, the installation of a collector sheeting from the drilled piles with the length of $30,0 \mathrm{~m}$ and diameter of $\varnothing 820 \mathrm{~mm}$ at the distance of $5 \mathrm{~m}$ from each side of the collector and the limitation of the piles length of building foundation (Fig. 1).

The sewer collector with the diameter of $3,6 \mathrm{~m}$ is built by shield tunneling method. The main bearing constructive elements of the collector are tubes with the width of $1.0 \mathrm{~m}$ and diameter of $3,6 \mathrm{~m}$.
The collector slope is $i=0,0005$. The collector consists of 7 tubes and an internal monolithic reinforced concrete «shirt» with a thickness of $140 \mathrm{~mm}$. Concrete is pumped between tubes and the shield tunneling through the openings in the tubing. Cross section of the collector is shown in Figure 2. The class of the collector concrete is $\mathrm{C} 25$ / 30. The tubing is reinforced by 5 steel rods with the diameter of $\varnothing 12 \mathrm{~mm}$ The reinforcement is of the periodic profile. The cross-section along the collector is shown in Fig. 2.

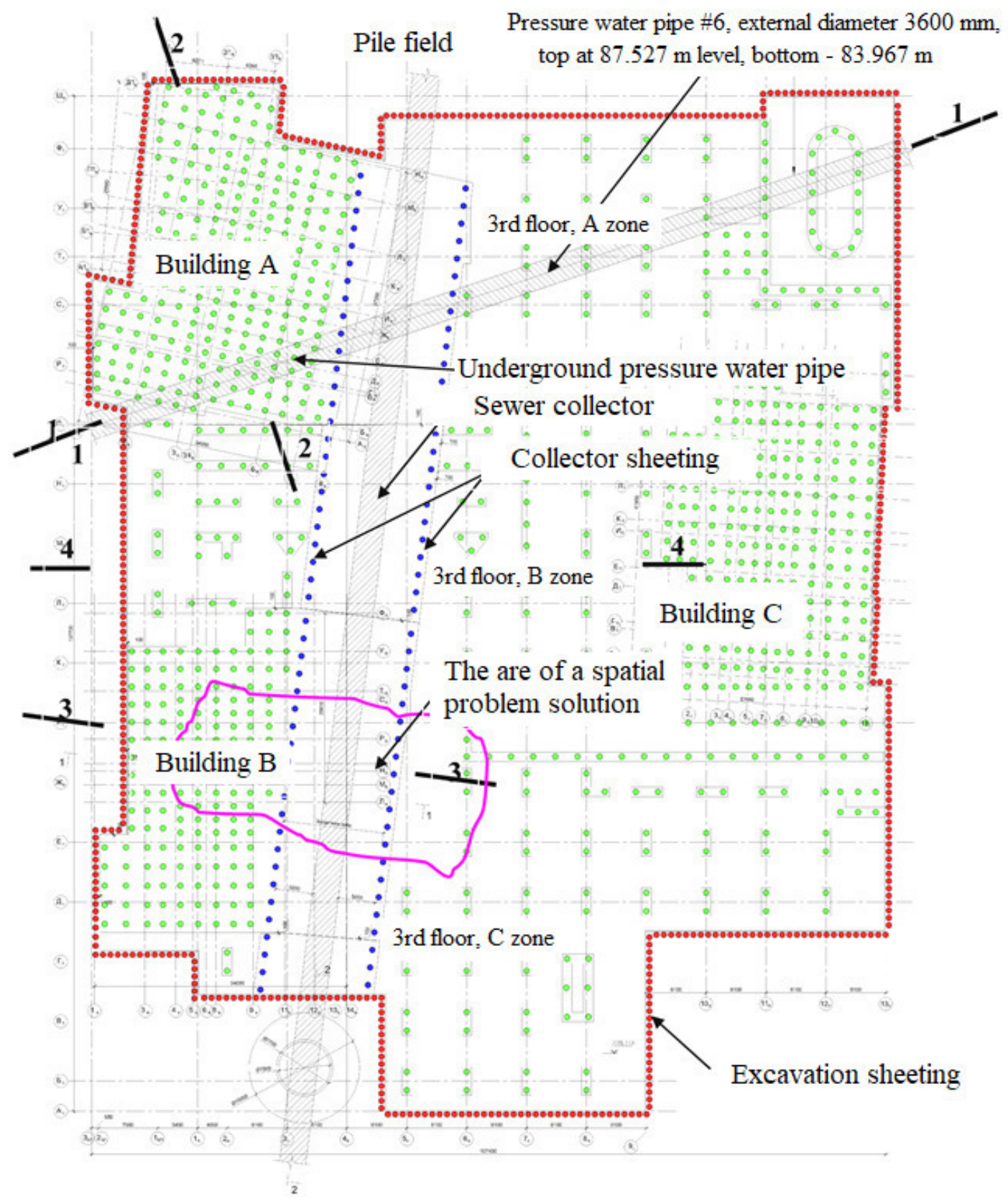

Figure 2 - Plot of the collector, the water supply, and the calculated cross sections 1-1...4-4 
The technical condition of the collector on the site is unknown since its visual inspection was not carried out, therefore the possible degree structural elements wear is taken by analogy with the collector section which was surveyed in 1999. In this case, the following damages have been recorded:

1) a reinforced concrete «shirt» of the main city collector, in the upper part corroded to tubing, lost its bearing capacity and purpose;

2) large strata of the «shirt» had separated from tubes and deposited in the collector tray;

3 ) the groundwater infiltration in the collector was recorded.
According to the conclusion of the Standing Committee on Technological and Environmental Safety and Emergencies executive body of the Kyiv City Council on the collector inspection, it is in an emergency state (minutes № 56 of 10/06/2009).

Pressure water pipe, which passes through the area of the designed residential complex, belongs to the Desnianskyi water supply system in Kyiv. The water supply system with a diameter of $3.56 \mathrm{~m}$ was constructed by a shield tunneling method. The design of the water supply system is shown in Fig. 3.

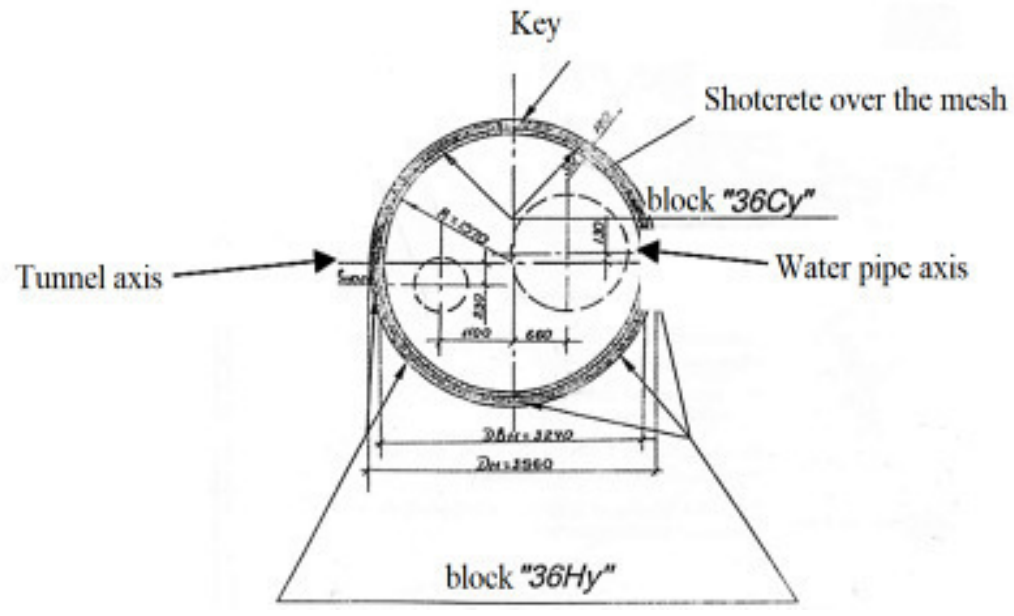

Figure 3 - The structure of underground water pipe

The main structural elements of the water supply are a metal pipe with a diameter of $1.32 \mathrm{~m}$ and reinforced concrete tubes with a diameter of $3.56 \mathrm{~m}$. The collector ring consists of 7 tubes that serve as a reinforced lining with the thickness of $160 \mathrm{~mm}$, and an internal monolithic reinforced concrete «shirt». The concrete is poured through the openings in the tubing in the space between the tubes and the shield tunneling. There is no data on the damage to the structures of the water supply, so it is impossible to judge the categories of the structures technical condition.

Concrete was injected into the space between the tubing and tunneling in the soil, the tubing concrete class is $\mathrm{C} 25$ / 30. The tubing reinforcement is made by 5 rods with the diameter of $12 \mathrm{~mm}$, the reinforcement is done with periodic profile.

In geomorphologic terms, the site is located on the left slope of the river Lybid valley. The relief of the site has a slight slope in the southwest direction. Absolute marks on the Earth surface vary from 133.90 to $140.20 \mathrm{~m}$.

The geological structure of the site to the explored depth of $50.0 \mathrm{~m}$ is composed of diluvia and glacial deposits complex, which is presented by sand, sandy loam, and loam, which are covered over by a fill-up soil. Under the diluvial deposits, there are sands of Kharkiv stage and the marl clay and loam of Kyiv stage. The geological structure of the construction site is composed of sand, sandy loam, loam, and clay covered over by a fill-up soil [9].

Hydrogeological conditions of the construction site are characterized by the presence of an aquifer, timed to diluvia sand, sandy loam [3]. The underground flow was registered by geotechnical surveys at absolute marks of $125.70 \ldots 128.90 \mathrm{~m}$. The complexity category of geotechnical conditions, according to DBN A.2.1-1:2008 «Engineering surveys for construction», is the third (complex) [9]. Underground waters are registered at a depth of $6.90 \ldots 11.80 \mathrm{~m}$, at the absolute marks of $125.70 \ldots 128.90 \mathrm{~m}$ and confined to diluvia sand and sandy loam.

Estimation of the SSS alteration of city sewer collector and underground water supply pipe soil base is carried out using finite element method. The calculations were carried out for the building A, which is located above the collector and the water supply pipe, and for the building, which is located above the city collector (Fig. 1).

Deformation module of the marl clay (EGE-10) according to the results of geotechnical surveys is $E_{1}=30 \mathrm{MPa}$, and according to the results of presiometric surveys is $E_{2}=50 \mathrm{MPa}$, so calculations for assessing the change in the SSS of soils within the collector and the water supply pipe were performed for these two values of the deformation module. These calculations were carried out in iterative manner using the Mohr-Coulomb model, which was used for the first 
approximation to soil existing state. The model includes five parameters: Young modulus $(E)$, Poisson ratio $(v)$, cohesion $(c)$, the friction angle $(\varphi)$ and the dilatation angle $(\psi)$. The program also considers soil volumetric weight in dry $\left(\gamma_{\text {unsat }}\right)$ and water-saturated $\left(\gamma_{s a t}\right)$ state, and also the coefficients of filtration $k_{x}$ and $k y$.

The soil massif is modeled by 15 nodal elements, where the soil with different physical and mechanical characteristics is distinguished by the $2^{\text {nd }}$ group of limit states. Boundary conditions in the lower part of the model presented in the form of a continuous fixed support, and vertical walls presented by roller supports.

Calculations on the assessment of the SSS alteration for the soil in collector and water supply system base are made considering and without consideration additional loads from the designed buildings foundations $\mathrm{A}$ and $\mathrm{B}$ and for calculation sections 1-1 ... 4-4.

The calculation scheme for section 1-1 is shown in Fig. 4.

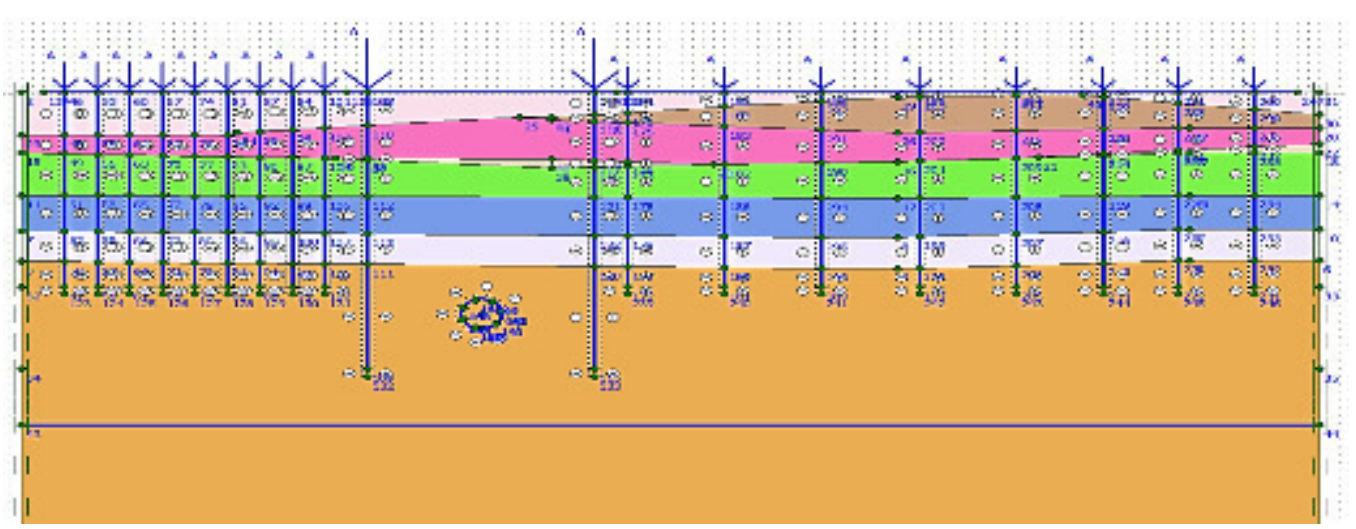

Figure 4 - The calculation scheme for section 1-1

Isolines of normal stresses $\sigma_{y}$ Along section 1-1 for phase 6 (considering residential complex weight when $E_{l}=30 \mathrm{MPa}$ ) are shown in figure 5, and sewer collector and water supply pipe structures deformation scheme - in figure 6 , isolines of vertical displacements - in figure 7.

The calculation was performed considering the sequence of complex construction for such phases:

1) soil massif at the excavation bottom level $128,15 \mathrm{~m}$

2) installation of the collector and water supply pipe;

3 ) the installation of piles for the sewer collector sheeting;

4) installation of piles for the foundation of the designed complex;

5 ) installation of plate foundation for the designed complex;

6) erection of a residential complex with a load of $700 \mathrm{kN} / 1 . \mathrm{m}$.

Maximum settling of the collector and the water supply pipe, considering residential complex weight for the sections 1-1, 2-2, 3-3, 4-4 (figure 1, when $E_{l}$ $=30 \mathrm{MPa}$ and $E_{2}=50 \mathrm{MPa}$ ) are shown in table 1 .

Normal stress distribution $\sigma_{y}$ along the perimeter of the collector when $E_{1}=30 \mathrm{MPa}$ and $E_{2}=50 \mathrm{MPa}$ for sections 1-1, 4-4, 3-3 are shown in table 2 .

For the determination of the tension occurring in the constructive elements of the collector and the water supply pipe, calculation was performed using «LIRA» software, whereas as the external loads, there were applied the stresses obtained from calculation of the SSS alteration for the soil around the collector and the water supply pipe. The simulation was performed using the «mounting» system. The modeling was carried out by three stages:

1) the natural state of the soil: enables to estimate the stresses in the soil from its own weight;

2) installation of the collector: enables to evaluate the stress arising in the designed elements of the collector and the water supply pipe;

3 ) installation of the pipe: enables to estimate the forces that arise in the structural elements of the collector and the water supply pipe from the additional load.

Assessment of the collector and water supply pipe structural elements technical state alteration was performed by increasing the main compressive and tensile stresses in the structural elements of the collector and the water supply pipe. In the calculations for estimating the alteration in the bearing structures SSS, the design concrete class of C25 / 30 was adopted.

Figures 8 and 9 respectively show the diagrams of the main tensile and compressive stresses in the collector (considering residential complex weight).

The main tensile stresses in the tubings' concrete of the collector during the erection of the structures' complex are $86 \mathrm{t} / \mathrm{m}^{2}$ (fig. 8), which does not exceed the calculated resistance to tension of $105 \mathrm{t} / \mathrm{m}^{2}$ (for the concrete class of $\mathrm{C} 25 / 30)$. 


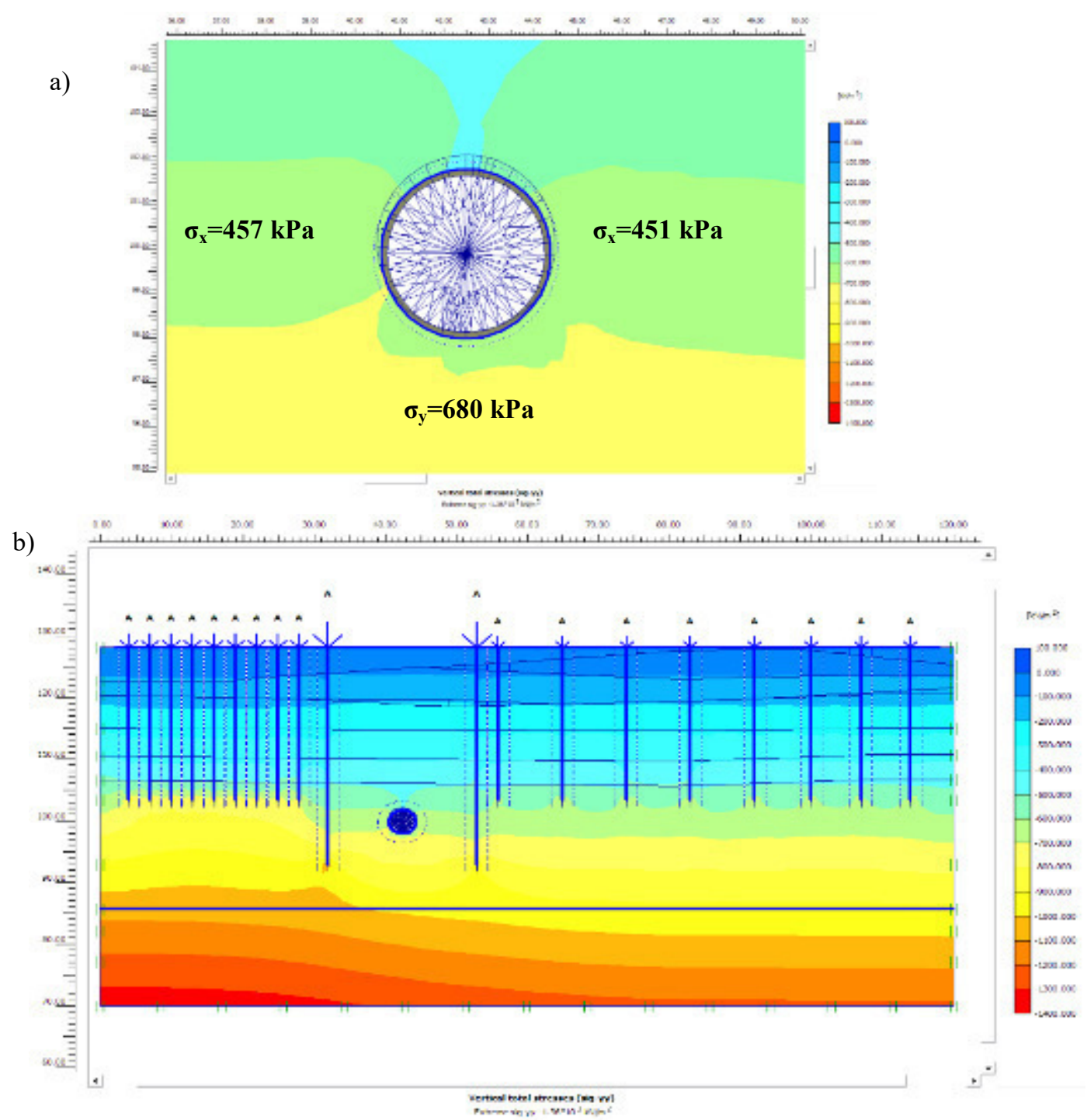

Figure 5 - Isolines of normal stresses $\sigma_{v}$

(taking into account the weight of the residential complex), phase $6\left(E_{1}=30 \mathrm{MPa}\right)$ : $\mathrm{a}-$ in the soil around the sewer collector; $\mathrm{b}$ - in the soil above the underground water supply pipe

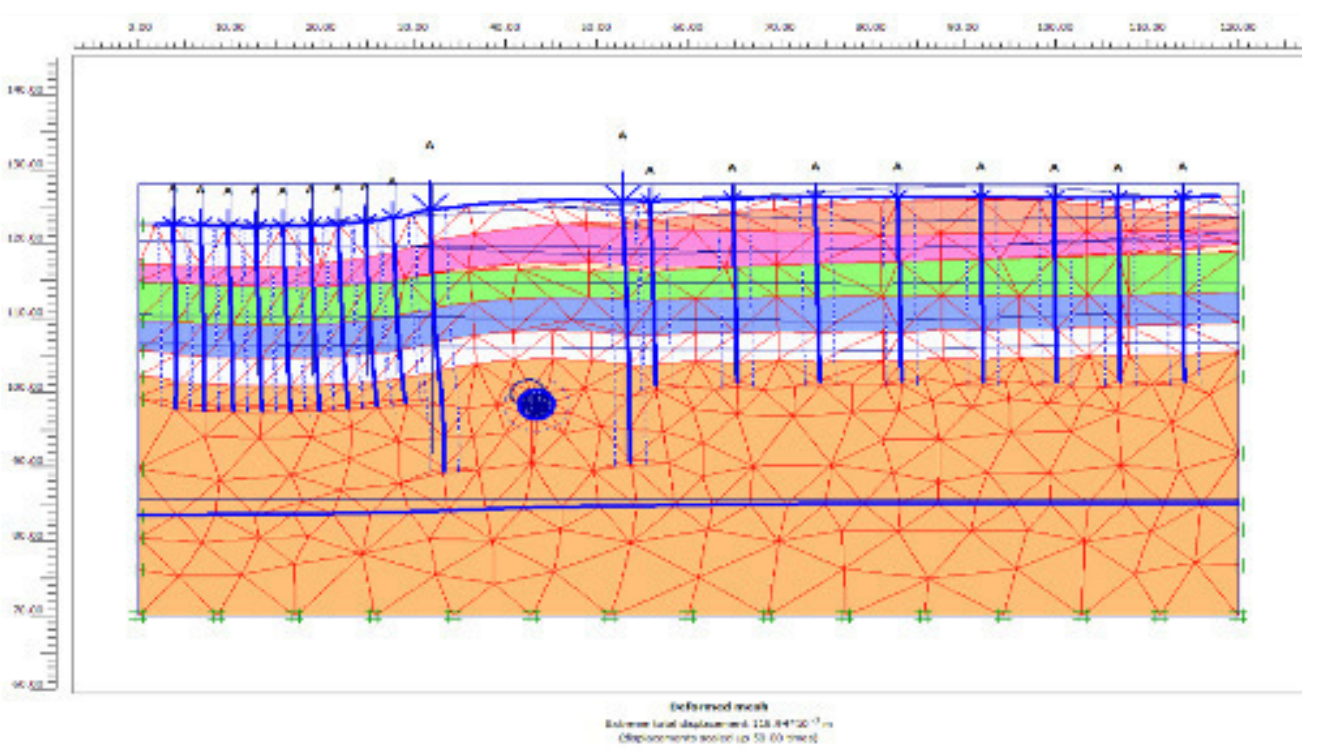

Figure 6 - The deformation scheme of sewage collector and water supply structures (taking into account the weight of a residential complex), phase $6\left(E_{1}=30 \mathrm{MPa}\right)$ 


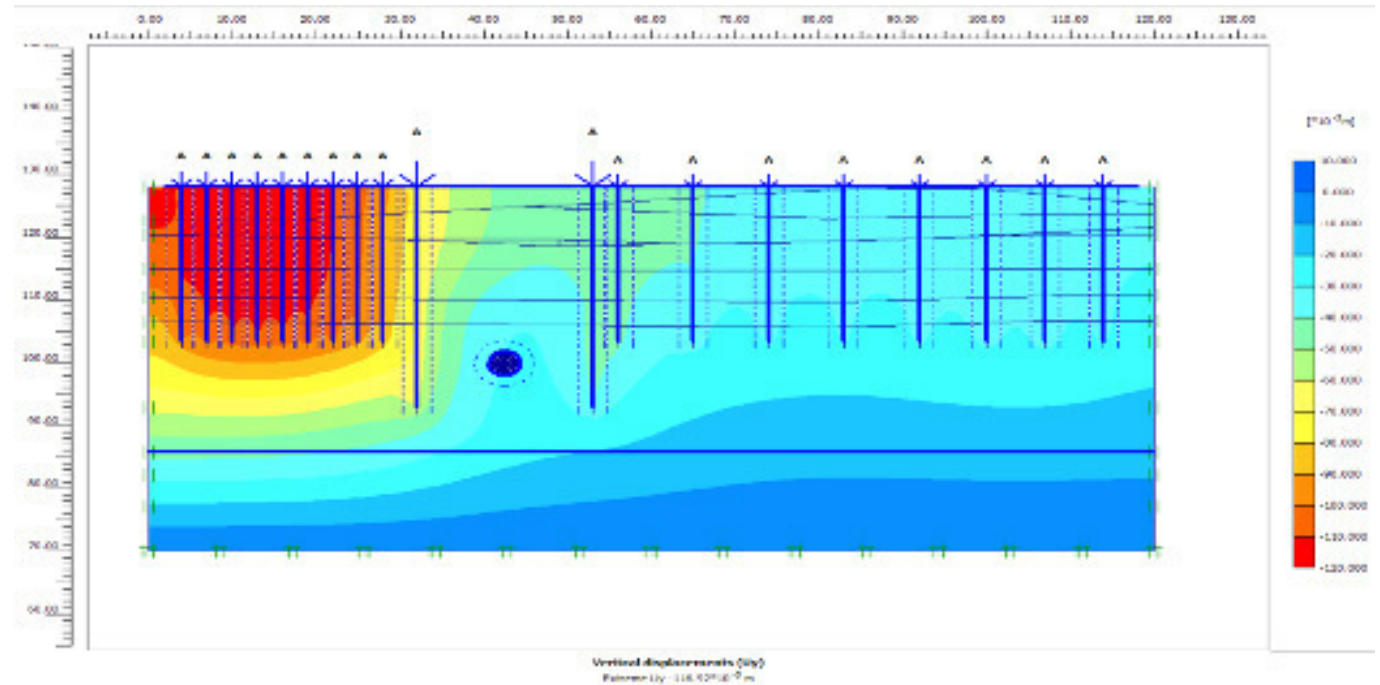

Figure 7 - Isolines of vertical displacements

(taking into account the weight of a residential complex $)$, phase $6\left(E_{1}=30 \mathrm{MPa}\right)$

Table 1 - Maximum settling of the collector and water supply system, taking into account the weight of the residential complex

\begin{tabular}{|c|c|c|c|c|c|c|c|c|}
\hline \multirow[t]{4}{*}{$\begin{array}{l}\text { The underground } \\
\text { structure's name }\end{array}$} & \multicolumn{8}{|c|}{$\begin{array}{c}\text { The maximum settling of the collector and water supply pipe taking into account the } \\
\text { weight of the residential, mm }\end{array}$} \\
\hline & \multicolumn{4}{|c|}{ Deformation module $E_{l}=30 \mathrm{MPa}$} & \multicolumn{4}{|c|}{ Deformation module $E_{2}=50 \mathrm{MPa}$} \\
\hline & \multicolumn{4}{|c|}{ Cross-sections (figure 1) } & \multicolumn{4}{|c|}{ Cross-sections (figure 1) } \\
\hline & $1-1$ & $2-2$ & $4-4$ & $3-3$ & $1-1$ & $2-2$ & $4-4$ & $3-3$ \\
\hline Collector & 32,8 & - & 10,0 & $12,0 / 10,0$ & 18,3 & - & 6,0 & $6,0 / 5,0$ \\
\hline Water supply pipe & 39,2 & 34,8 & - & - & 23,6 & 21,7 & - & - \\
\hline
\end{tabular}

Table 2 - Normal stress distribution $\sigma_{y}$ along the perimeter of the collector

\begin{tabular}{|c|c|c|c|c|c|c|}
\hline \multirow{4}{*}{$\begin{array}{l}\text { Nods } \\
\text { number }\end{array}$} & \multicolumn{6}{|c|}{ Stress, $\mathrm{kPa}$ when the deformation module is $E_{l}=30 \mathrm{MPa}$} \\
\hline & \multirow{2}{*}{\multicolumn{3}{|c|}{$\begin{array}{l}\text { Without accounting for the weight of the residen- } \\
\text { tial complex } \\
\text { Cross-sections (figure 1) }\end{array}$}} & \multirow{2}{*}{\multicolumn{3}{|c|}{$\begin{array}{l}\text { Taking into account the weight of the residential } \\
\text { complex (700 kN/l.m.) } \\
\text { Cross-sections (figure 1) }\end{array}$}} \\
\hline & & & & & & \\
\hline & $1-1$ & $4-4$ & $3-3$ & $1-1$ & $4-4$ & 3-3 \\
\hline 1 & 467 & 466 & 466 & 487 & 505 & 519 \\
\hline 2 & 465 & 456 & 456 & 451 & 491 & 491 \\
\hline 3 & 608 & 603 & 603 & 680 & 667 & 685 \\
\hline \multirow[t]{2}{*}{4} & 466 & 457 & 457 & 457 & 491 & 491 \\
\hline & \multicolumn{6}{|c|}{ Stress, $\mathrm{kPa}$ when the deformation module is $E_{2}=50 \mathrm{MPa}$} \\
\hline 1 & 410 & 461 & 462 & 462 & 491 & 508 \\
\hline 2 & 383 & 475 & 462 & 468 & 504 & 543 \\
\hline 3 & 584 & 602 & 598 & 661 & 655 & 679 \\
\hline 4 & 380 & 477 & 463 & 474 & 503 & 536 \\
\hline
\end{tabular}






Figure 8 - The diagram of the main tensile stress in the collector (taking into account the weight of the residential complex)

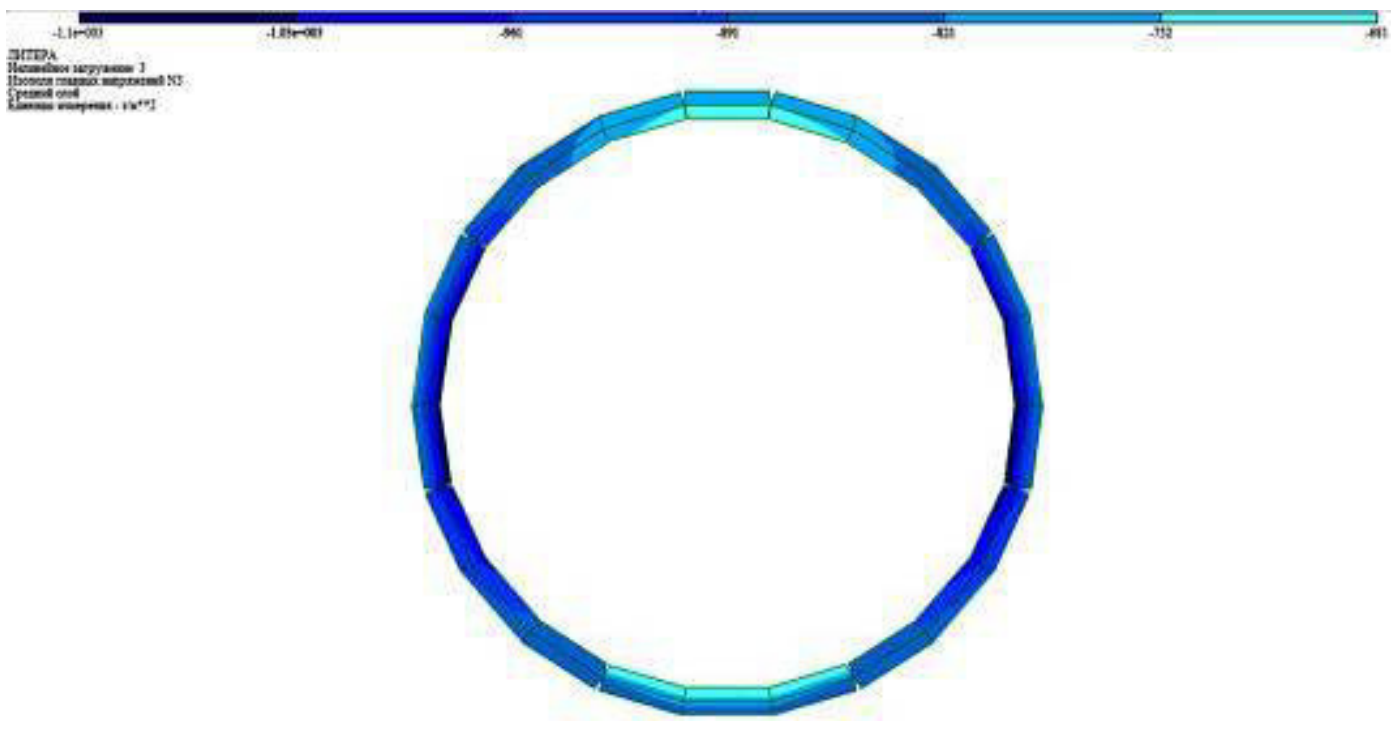

Figure 9 - The diagram of the main compressive stress in the collector (taking into account the weight of the residential complex)

The main compressive stress in the tubing concrete of the water supply pipe during the erection of the structures' complex is $1100 \mathrm{t} / \mathrm{m}^{2}$, which does not exceed the calculated resistance of the concrete to the tension of $1450 \mathrm{t} / \mathrm{m}^{2}$ (for the concrete class of C25/30).

Scientific and technical support should be carried out for complex construction or reconstruction objects, special geotechnical, hydro-geological, engineering-ecological conditions and complex relief; structures in the zone of influence (risk) of new construction (reconstruction) or areas where dangerous geological processes are possible [10].
Monitoring is carried out at the stages of designing and construction, as well as reconstruction and preservation operations for significant consequences of $\mathrm{CC} 3$ - in all cases, $\mathrm{CC} 2$ - in complex geotechnical conditions, in areas of a dense housing, in the new construction or reconstruction influence zone [11]. Monitoring at the construction and operation stage for a functional purpose should include visual-instrumental physical observations and survey (including geodetic control) of structures, bases, territories, hydrogeological and ecological observing system, and results analysis. 


\section{Conclusions.}

1. The technical decision on reducing the load on the collector (the absence of piles directly over the collector, the use of shut-off pile rows for the collector sheeting has significantly reduced the impact of the residential complex on the collector.

2. The stresses in the bearing elements of the collector tubing and the water supply system, considering residential complex loads, do not exceed the designed values of concrete resistanc(class of concrete C25/ 30).

3. The loading from the projected residential building during the construction and operation period does not lead to deterioration of the existing technical condition of the collector and water supply structures provided that the actual physical properties of the collector and water supply tubing materials to the design value are matched.

\section{Recommendations.}

1. In order to exclude the possible emergency situation at the collector and / or water supply, inspection and assessment of the collector and water supply structures technical condition should be undertaken as well as their physical deterioration and the effect of collector and water supply structures subsequent operation on the designed residential building in terms of its reliable and safe exploitation conditions.

2. Evaluate the impact of building the residential complex on the existing surrounding housing.

\section{References}

1. ДБН В.2.1-10:2009. (2009). Основи та фундаменти споруд.Основні положення проектування. Київ: Мінрегіонбуд України, ДП «Укрархбудінформ».

2. ДБН В.2.1-10:2009. (2011). Основи та фундаменти споруд.Основні положення проектування. Зміна №1. Київ: Мінрегіонбуд України, ДП «Укрархбудінформ».

3. ДБН В.2.1-10:2009. (2012). Основи та фундаменти споруд.Основні положення проектування. Зміна №2. Київ: Мінрегіонбуд України, ДП «Укрархбудінформ».

4. ДБН В.1.1-45:2017. (2017). Будівлі і споруди в складних інженерно-геологічних умовах. Загальні положення. Київ: Мінрегіонбуд України, ДП «Укрархбудінформ».

5. ДСТУ-Н Б В.1.1-39:2016. (2017). Настанова шодо інженерної підготовки грунтової основи будівель і споруд. Київ: Мінрегіонбуд України, ДП «Укрархбудінформ».
6. ДСТУ-Н Б В.1.1-40:2016. (2017). Настанова щодо проектування будівель і споруд на слабких грунтах. Київ: Мінрегіонбуд України, ДП «Укрархбудінформ».

7. ДСТУ-Н Б В.1.1-44:2016. (2017). Настанова щодо проектування будівель і споруд на просідаючих грунтах. Київ: Мінрегіонбуд України, ДП «Укрархбудінформ».

8. Будівництво житлово-адміністративного комплексту з вбудованими та прибудованими приміщеннями громадського і торгівельного призначення та надземним і підземним паркінгами по вул. Анрі Барбюса, 39/2 в Печерському районі м. Києва. Стадія проект. (2011). Київ: ТОВ «ВIP - РМ».

9. Звіт про інженерно-геологічні вишукування майданчику під будівництво житлово-адміністративного комплексту по вул. Анрі Барбюса, 39/2 в Печерському районі м. Києва. I етап. Стадія «П». Об'єкт: «Бдівництво житлово-адміністративного комплексту по вул. Анрі Барбюса, 39/2 в Печерському районі м. Києва . Арх. №12212. (2008). Куіv: ДП Міністерства оборони України «Центральний проектний інститут».

10. ДБН В.2.1-5:2007. (2009). Науково-технічний супровід будівництва об'єкту. Київ: Мінрегіонбуд України, ДП «Укрархбудінформ».

11. ДСТУ-Н Б В.1.2-17:2016. (2017). Настанова щодо науково-технічного моніторингу будівель і споруд. Київ: Мінрегіонбуд України, ДП «Укрархбудінформ».

12. Kryvosheiev, P., Farenyuk, G., Tytarenko, V., Boyko, I., Kornienko, M., Zotsenko, M., Vynnykov, Yu., Siedin, V., Shokarev, V. \& Krysan, V. (2017). Innovative projects in difficult soil conditions using artificial foundation and base, arranged without soil excavation, Proc. of the $19^{\text {th }}$ Intern. Conf. on Soil Mechanics and Geotechnical Engineering (Sep. 17 - 22, 2017 / COEX, Seoul, Korea). Retrieved from https://www.issmge.org.

13. Dvornyk, A. (2018). Numerical modeling of structures fencing deep excavations of complex configuration. Proc. of the $26^{\text {th }}$ European Young Geotechnical Engineers Conf. (Sep. 11 - 14, 2018 / NAWI Graz Geocenter, Austria).

14. EN 1997-1:2004. Eurocode 7: Geotechnical design Part 1: General rules . 